\title{
Islands and the world from an anthropological perspective
}

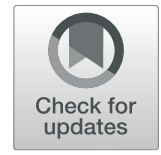

\author{
Guoqing Ma
}

Received: 16 July 2020 / Accepted: 3 September 2020 / Published online: 16 October 2020 (C) The Author(s). 2020 Open Access This article is licensed under a Creative Commons Attribution 4.0 International License, which permits use, sharing, adaptation, distribution and reproduction in any medium or format, as long as you give appropriate credit to the original author(s) and the source, provide a link to the Creative Commons licence, and indicate if changes were made. The images or other third party material in this article are included in the article's Creative Commons licence, unless indicated otherwise in a credit line to the material. If material is not included in the article's Creative Commons licence and your intended use is not permitted by statutory regulation or exceeds the permitted use, you will need to obtain permission directly from the copyright holder. To view a copy of this licence, visit http://creativecommons.org/licenses/by/4.0/.

\begin{abstract}
Island studies play an important role in the development of anthropology. It is of academic value and practical significance to understand the island world as the field where multiple modernization forces and globalization interwine. This paper explores the intricate and diverse connections between continental and marine culture from a perspective of "viewing the world through the island". In terms of overall diversity and exoteric mobility, this paper reviews the various aspects of island studies, examines the internal and external transformation of islands within land-sea interaction, and analyzes the dynamic historical process of the island world's involvement in the global network, which blends and integrates various cultural elements of the external world. In the context of globalization, the island world is undergoing dramatic changes and in coping with them generating its new features.
\end{abstract}

Keywords Island studies · Island world - Sea studies · The South China Sea rim · Globalization

\section{Introduction}

An island is "a land area completely surrounded by water" (Royle 2007). According to the statistics on the 180,498 islands found around the world (excepting

G. Ma $(\bowtie)$

School of Ethnology and Sociology, Minzu University of China, Beijing, China

e-mail: hssmgq@mail.sysu.edu.cn 
Greenland) collected by Global Shoreline Database, islands account for only $1.47 \%$ of the earth's surface area. ${ }^{1}$ Based on relevant statistics from 2006 , approximately 550 million people lived on islands, making up $10 \%$ of the world population. One quarter of sovereign states around the world were composed of islands or archipelagos, while the continents including islands and their exclusive economic zones make up more than one-sixth of the earth's surface area (Baldacchino 2006).

In recent years, oceans have increasingly become a hot topic of academic research. Islands have aroused the research interests of scholars in different disciplines due to their distinct natural ecologies and social cultures so different from the continent. In order to strengthen the exploration of islands, the International Small Island Studies Association was established in 1992; while in Japan, the Island Research Society (Nihon-Tosho-Gakkai) was established in 1997. With the increasing emphasis of different disciplines on island studies, the very first academic institute of island studies was founded at University of Prince Edward Island in 2003, which brought together a large number of multi-disciplinary experts and scholars who were dedicated to island studies. Among them, Canadian island researcher Godfrey Baldacchino pointed out that island studies were not confined to a single discipline, nor to a specific methodology, but rather included interdisciplinary research. He proposed the concept of "islandness", which is used to study the physical property and social events of islands as an intervening variable to know about them. In Baldacchino's (2006) point of view, island studies focus on the composition of islandness as well as its impact on ecology, human behavior, political economy, social culture, tourism, development, and other dimensions. This concept covers various issues of concern to the natural sciences and humanities and social sciences, and forms an inter-disciplinary, comprehensive island studies.

The unique ecological environment of islands endows four cultural characteristics, as follows: firstly, the geographic space of islands determines their isolation from continental culture; secondly, the ecological environment of islands determines their marine-focused characteristics of culture; thirdly, islands have maintained considerable historic significance over time; finally, the mobility and cross-border nature of islands plays a transitional and connecting role in the land-sea interaction from the perspective of cultural transmission. Islands are a connecting point between land and sea, and can be regarded as a station on the route of a sea passage. In the formation of a global system, islands became both the major subject and main embodiment of marine culture. In ocean studies, we term the linkage system between islands as "the island world," the study of which helps us to understand the historical process of mutual influence and cultural exchange between different cultures and different ethnicities on the island. In fact, anthropology has a long historical tradition in the study of island society and its ethnicities.

With the intensive global-local interaction, as a field affected by modernity, current island societies and cultures are undergoing complicated changes. Observing the whole world through the lens of islands helps us to reflect the relationship

\footnotetext{
${ }^{1}$ http://www.ngdc.noaa.gov/mgg/shorelines/gshhs.html, accessed April 11, 2015.
} 
between "islands of the world" and "the world of islands". This paper examines island studies in the context of a world system and its developing process, observes islands under "continentalization" and globalization by centering on the South China Sea Rim, reviews how the region coped with dramatic transformation to maintain its original socio-cultural characteristics and thus brought forth new development.

\section{Anthropological island studies: the island world formed by the land-sea interaction}

Island studies have always played a significant role in the discipline history of anthropology. In fact, early island studies by Western anthropologists can be seen as the unexpected fruit of Western colonial activities. Islands are relatively isolated from their mainland, which helps to preserve a variety of "exotic customs", exactly the most desirable targets for anthropologists in the discipline's early days. From 1898 to 1899 , British anthropologist Alfred Cort Haddon twice led a team from Cambridge University to do research in the Torres Strait, establishing the basic norms for modern anthropological fieldwork and obtaining valuable first-hand documentation. In 1908, William H. R. Rivers did fieldwork in Melanesia, in the southwest Pacific Ocean, while C. G. Seligman did his in New Guinea and Sri Lanka. Japanese ethnologist Torii Ryuzo carried out his detailed fieldwork in East Asia and the Pacific Islands. Later, Bronislaw Malinowski's study of the Trobriand Islands and Alfred Radcliffe-Brown's study of the Andaman Islands jointly announced the birth of modern scientific ethnography. Moreover, Margaret Mead's study of Samoa and the Admiralty Islands, Raymond Firth's study of Tikopia Island drew quite a lot of attention. During that period, early anthropologists tried to seek answers by bringing into islands their consciousness of continental problems and confusions, in turn, they reflected Western society through the lens of exotic island cultures, in particular, through the kinship systems, social structures, economic trade, religious rituals, education and psychological cognition. However, these "on island" studies neglected indigenous cultures and the particularities of islands, and were limited to continental thinking.

From the 1950 s to 1960 s, along with their in-depth island studies, anthropologists began to realize that the concepts and methodologies developed from continental studies weren't capable of explaining island societies. Based on his fieldwork on Saint John's Island in the Caribbean, American anthropologist Manners (1965) pointed out that it was quite a naïve idea for traditional anthropologists to consider islands free from outside influence and pressure. Viewing islands in the context of globalization, we need to break disciplinary traditions and explore new approaches to truly understand island societies. Starting from the Trobriand Island study by Malinowski, anthropologists emphasized "local opinions", that is, they attached importance to local people's own explanations of their culture, and tried to interpret them. Geertz (1983) even put forward the theory of "experience-near" and "experience-distant". The facts and narratives that had been avoided by those "explorersdiscoverers-colonists" were supplemented by the voices of modern anthropological 
introspection and islands' "managers-servants-environmentalists," calling for abandoning the continental approach, standing with local points of view, and respecting local concepts and expressions (Baldacchino 2008). In fact, islands have already shown their mixture, complexity, and globalization in terms of localization, transformation, and migration, and were no longer confined to the internal and external perspective, thereby bringing forth new topics for anthropologist to explore and new approaches to develop for island studies.

The recognition and interpretation of island cultures within anthropology has three fundamental features. Firstly, "isolated islands are actually not isolated." People tended to consider islands as culturally isolated and thus neglected their openness and connections to the outside. Anthropologists recognized this connection a long time ago: Malinowski's study of the "Kula Ring" formed by the exchange relation between different islands, which was indeed a trade system, demonstrated islands in a network system. Secondly, island cultures themselves are relatively stable, and as such, they are an important field for time-space conversion studies of "center" and "edge". There are certain connections between different island cultures that suggest internal cultural stability much stronger compared to the continental culture, particularly on Asian islands. Many groups arrived on islands due to migration, war, and change of dynasties, etc., bringing with them continental cultural features; in turn, the weakening and disappearing continental cultural features being preserved on islands, as expressed in the old saying, "pursuing lost civilization from remote folk society", helps us to better understand the culture center through the island edge. Thirdly, island cultures were usually borderless (especially before the formation of nation-states); therefore islands were a significant field for reflection on colonialism and post-colonialism. These are also hot topics within anthropological island studies. In history, most islands used to be colonized by Western countries, and whether in the past or at present, island residents are still identified as "others" in Western narratives and documents. In the reality of globalization and island transformation, scholars began to take a retrospective approach to island studies to help it to regain academic attention.

As mentioned above, anthropological island studies include the fieldwork and research on islands, and island chains as well as the "island world" based on anthropological theory and methods. In the context of global time-space, we should explore the wholeness of island societies and their cultural diversity from a peopleoriented perspective, and understand the historical process of interaction and exchange between different civilizations and between different ethnicities on islands so as to enrich our knowledge of types of civilizations and their evolution.

McCall (1996) put forward the concept of "nissology", promoting the theoretical development of island studies. He clearly pointed out that, if we recognized the twentieth century as a period of continental, large-regional and industrial development, then the twenty-first century should be the time for island, small-scale, and service-oriented development, therefore, the perspective of "the world of islands" rather than "islands of the world" should be highlighted. On this basis, this paper emphasizes the modernity and network feature of the island world, explores the intricate multiple-networks relationship between oceans and continents in the process of continentalization, and examines the island world as a part of global society 
from an open and mobile perspective. The so called "island world" contains at least two implications: firstly, islands are where continents and oceans converge and mingle. Their cultures are not simply transplanted from the outside, but what has been introduced has undergone an interactive integration with local culture; secondly, islands are not a partition between the land-sea interaction, but rather a connecting point through which island ports and island cities, as "island chains", connecting a tremendous global network that is being established between land and sea.

Therefore, the formation of the island world is actually a historical process from static involvement to dynamic involvement into the global system. In socio-cultural studies of oceans, islands, as an important station on the sea, are the essential media that connects the ocean world with the continental world. The social network and cultural exchange established during the process of migration, marine trade, and even religious transmission and localization, connect the small island with the big world and constitute an island world, which not only reflects its unique cultural traits, but also manifests the globalization process.

\section{The South China Sea rim: multiple cultural circles formed by the land-sea connection}

According to historians, "interaction" is the existence pattern for human societies, none of which is closed or isolated, and all of which instead inevitably exist in interaction with the outside world, becoming a connected system or a network with impacts on each other (Xincheng 2009). Taking the Pacific islands as an example, in traditional thought, these islands' societies, scattered on the Pacific, must be isolated from other cultures to an extent, due to its poor transportation and natural isolation. That is definitely not true. As mentioned above, Malinowski's study of the "Kula Ring" showed that the fishermen living on the islands constructed an interactive relationship network and a trade system under certain regulations between different islands by means of the simple and agile canoe (Malinowski 2009). The studies by Marshall Sahlins and J. R. McNeill further illustrated that the Pacific islands had intensive interaction with the outside since at least the Age of Captain Cook, including the flow of people and goods (Sahlins 2003; McNeill 2010). Therefore, a wider and macroscopic perspective is needed to study the "small place," that is, island society, in an anthropological sense, that views the research subject as an all-around connecting point within a network or a region, thus enabling researchers to sense the existence and impact of other points and circles. The study of the South China Sea Rim offers exactly such a perspective.

Lying between the largest continent (Eurasia) and the largest ocean (the Pacific), the South China Sea has cragged coastlines, numerous islands and peninsulas, as well as various climate types and ecological environments due to the confluence of the Indian and Pacific Oceans. There are seven out of China's ten archipelagos, ${ }^{2}$

\footnotetext{
${ }^{2}$ Including Nanri, Wanshan, Chuanshan, Dongsha, Xisha, Zhongsha and Nansha Islands.
} 
and twenty-eight out of forty-five of its chain islands located here. ${ }^{3}$ In terms of area, extraordinarily large islands over $2500 \mathrm{~km}^{2}$ only include Taiwan and Hainan; nine of China's fourteen large islands, with an area between 100 and $2500 \mathrm{~km}^{2}$ each, are in the South China Sea; seventy of China's 133 mid-sized islands with an area between 5 to $99 \mathrm{~km}^{2}$ each are in the South China Sea. With regard to China's small islands that are between 500 square meters to $4.9 \mathrm{~km}^{2}$ each, $98 \%$ are located in the South China Sea, and most are uninhabited islands and lack of freshwater resources. In general, only $23 \%$ of the total number of islands in the country are located in the South China Sea (Kexin and Jiagang 2002), however, this sea holds all the extraordinarily large islands, $70 \%$ of archipelagos, nearly two-thirds of large islands, and more than half of mid-sized islands. ${ }^{4}$

The South China Sea has historically been the boundary of Chinese cultural circle, the major axis of which starts from Singapore in the southwest to Taiwan in the northeast, and stretches about 1500 nautical miles in length; the short axis of which starts from Vietnam and goes to Sabah, Malaysia, stretching about 480 nautical miles. There are 230 islands in total within the South China Sea Rim, not a single one of which is more than 370 nautical miles away from the continent (Lihai 1995).The South China Sea is of irreplaceable economic and strategic importance.

The South China Sea islands preserved quite a lot of cultural characteristics, witnessed the land-sea interaction, and contained differences and similarities at the same time during the cultural transmission and integration process. These islands are the transition and connection between different cultures and different civilizations like a station on the sea, witnessing the process of China's becoming a global power, and serving as a window for the world to know China. Between mountains and the sea, there is a mixed world, in which islands serve as a transfer station or a springboard for people and products moving back and forth. The South China Sea Rim has become a cross-regional social network due to its fishery production, inbetween marine trade, cultural exchange, and port cities development.

Over the years, scholars have had extensive discussions and data compilations on the sovereignty issues of the South China Sea islands. Materials like fishermen's Book of Sea Routes, oral folk legends, and port relics need to be further explored. There are also many historical texts in the neighboring countries of the South China Sea, the collection and research of which can enrich the evidences of China's sovereignty over the region. Moreover, the thorough discussion of the sea boundary which demonstrates the transformation process in the history of islands will contribute to more knowledge about their development. Fishermen in the South China Sea were a group of people with mobility as its main feature, different from the farmers that were attached to their native land in a farming society. In a fishing society living on the sea, the concept of boundary has always been vague as there is no clear boundary for fishermen at all. They shuttled freely through different sea areas for production and operation, communicated and interacted

\footnotetext{
${ }^{3}$ There are eight in Fujian, one in Taiwan, eighteen in Guangdong, and one in Hainan.

${ }^{4}$ In addition, volcanic islands accounts for $0.1 \%$ of the total number of islands in the country, all of which are located in the Taiwan sea; coral islands accounts for $1.6 \%$ of the total number of islands in the country and all are located in Hainan, Taiwan and Guangdong.
} 
frequently with each other, and therefore formed a complex interactive marine network. The South China Sea Rim where fishermen work and live has always been an integrated area of geography, cultures, and ethnicities. The human geography of the South China Sea is extremely complicated, resulting from the interaction between ethnicities and also providing the basis for current exchanges.

Before Western colonial expansion, islands were involved into the global system naturally by way of trade and religious transmission. For example, the South China Sea had been incorporated into the global market since the thirteenth century (Abu-Lughod 1989). Chinese ceramics, tea, silk product and Southeast Asian spices, rubber, tin, and birds' nests started flowing worldwide, the flowing tunnel was called the road of tea, the road of spices, the road of ceramics and the road of silver, etc. Now it is collectively called "The Maritime Silk Road."

Islands played a significant role in the spice trade of the South China Sea. Some scholars have taken the Maluku Islands of Indonesia as an example and deduced that earlier than the tenth century, ancient Asian and Roman businessmen started to import cloves and nutmeg from central Vietnam, southern Thailand, the Malay Peninsula, and Java into the Chinese market. With the increase in the spice trade, Chinese businessmen opened a northbound route from the southeast coast of China to north Maluku via the Philippines' Sulu Islands, and they did business with aboriginal Maluku people no later than the fourteenth century. During the process of trade expansion and sea route opening, Java and Sumatra became the main distribution centers for Chinese and Arab businessmen to obtain cloves and nutmeg (Zhongqing 2015). With islands, even island ports, as junctions, the continuing and complicated migration and cultural exchange in the South China Sea could be fully understood in this cross-regional market system. Furthermore, islands connected the region with the whole world, and the whole world's trade system as well.

At the turning from the fifteenth to the sixteenth century, the whole world became a unity based on islands as the result of the "Great Geographical Discovery." Sea-borne plunder, marine trade, and overseas colonization were the major means of primitive Western capitalism accumulation. Along with the global expansion of capitalism, the whole world became what Immanuel Maurice Wallerstein called "the capitalist world system." In this synthesis that contained political, economic, and cultural elements, the Western center of this capitalist system integrated the peripheral and marginal regions and countries into the world system (Wallerstein 2013), and the Pacific and Caribbean Islands were so colonized, one after another. The active process of islands' involvement into the global system became a passive one, causing ethnic confrontation and integration on one hand and bringing forth many cultural implications beyond the political and economic scope on the other.

As an important point in the South China Sea trade network, islands are also a station for merchandise exchange on "The Maritime Silk Road." The fishery and seafood trade correspondingly formed a trading network on the South China Sea. Based on the studies on Tanmen port fishermen (Wang 2015), scholars have pointed out that during the age of sailing, fishermen pursued free marine production activities, and sailed to southeastern countries to conduct trade activities centering on Thailand, Vietnam and Singapore. Taking deep-sea diving fishery as their 
major means of livelihood, these fishermen weaved a cross-regional social network on the South China Sea along with the flow of production and trade. Due to fishery production and marine trade, Hainan and other islands on the South China Sea were unified with the whole of Southeast Asia, which enhanced cultural exchange and ethnic interaction between Hainan and Southeast Asia, formed a tradition of production collaboration based on opening and sharing marine resources, and therefore constituted a free, stable and well-organized island network. Based on historical documents and fieldwork studies of the new village port Lingshui, on Hainan, some scholars have stated that according to their production and life, fishermen of this village port were the earliest developers and historical witnesses of the South China Sea and its islands in China, and practitioners of safeguarding it in today's environment (Li 2014).

The Sulu Sea was a historically large social circle with the coexistence of multiple cultures and ethnicities. As a connecting point between the Indian Ocean and the South China Sea, the Kingdom of Sultanah Sulu, located at the southernmost point of today's Philippines and bordering Malaysia and Indonesia, witnessed frequent international marine trade. Meanwhile, it was an important area for interaction and exchange between fishermen who came from different places. After the Second World War, the influence and trade circle of the Kingdom fell apart as its borders got subordinated to different nation-states, therefore the fishermen who once worked in this area were accordingly divided into those nations. Even though under the influence of different nation-states, fishermen of these three nations who live in the area still constitute a unique fishermen's network in the form of fishing, trade and intermarriage. ${ }^{5}$ In real life, mobility has always been a major part of social life either in an island fishery society or in an inland farming society. In regional social studies, "mobility" is both a core concept and a key word for studying relationship and structure.

As an important junction between land and sea, islands are also a transfer station or a springboard for cultural exchange and transmission. Besides the flow of trade, religious transmission is also an important aspect of island-world relationship studies that serves as an important perspective of island reexamination. In the transmission process of island culture, relevant cultural practices and resource sharing issues arose in various ethnic religious concepts and practices. The most famous folk religion of the South China Sea is the Mazu belief, which widely exists in the island world. Mazu originated from Meizhou Island of Fujian province, where can be found the only ancestral temple of Mazu that has been the center of pilgrimage for believers since the Song dynasty due to its historical inheritance and the worldwide reach of the belief. The ancestral temple was the spiritual source of Mazu, to which other Mazu temples around the world should pay their homage and offer incense now and then to be blessed continually. For believers (especially in Taiwan), the identification of Mazu temple was embodied in the identification of Chinese culture. According to the "registration of regional Mazu temples under Meizhou Mazu ancestral temple" in 2008, there were a total of 138 temples registered in inland provinces, Hong Kong, Taiwan, Singapore and

\footnotetext{
${ }^{5}$ https://synodos.jp/international/7011//, accessed October 11, 2018.
} 
Malaysia (Wu and Jinyan 2015). The "oceanity" and mobility of islands promoted specific folk beliefs. From Meizhou to the whole world, the spread of Mazu belief not only reflects the regional religious similarity of the island world, but also connects the island with the world.

Islands, as a transfer station for religious transmission, demonstrated different features. Located in the south of Beihai, Guangxi province, Weizhou Island is the biggest island in Beibu Bay and was a transportation hub and a coastal stronghold throughout its history. In 1867, the Qing government reopened the island, and two French priests came to stay in the island with believers and brought forth a new wave of Catholic mission activitives in Guangxi province. Relying on its unique geographic location and cultural characteristics, Weizhou Island became a window for Guangxi's foreign contact along Beibu Bay (Jing and Zhu 2007). The introduction of Catholicism into Guangxi via the springboard of Weizhou Island also laid the distribution pattern of Catholicism in the region. Lying at the southwest of Taishan in Guangdong province, Shangchuan Island is adjacent to Hong Kong, Macau, and Zhuhai in the east, covering an area of $157 \mathrm{~km}^{2}$. Shadi fishing port in its south is one of the five largest fishing ports in Guangdong province. This island holds a unique and important position in the history of Christian missionary activity and foreign trade in China. During the first half of the sixteenth century, Shangchuan Island was one of the first informal trading ports and residence areas for Portuguese businessmen, who were the first Westerners in Guangdong. When long-voyage merchant ships traded with Chinese businessmen on the island, missionaries were present. Francois Xavier was one of the missionaries who arrived on the island twice, in 1551 and 1552; passed away on the island after his second arrival (Zhaorui 2006). Francois Xavier opened the gate of China and paved the road for followers. After him, the Jesuits swarmed into China and create the third climax of Christianity's dissemination in China (Sheng 2008). From then on, Shangchuan Island gradually became a holy place for Christians, with countless pilgrims coming to visit. Its function as the channel of foreign trade has been gradually decreased with the development of coastal trading ports, however, its symbolic status as the religious geographical point from which Christianity was introduced into China has been constantly elevated. For Europeans, the island represented the religious transmission of the world's entry into China.

In the context of natural environment, traffic location, and social culture, the South China Sea and its surrounding areas are not only the birthplace of various Asian marine cultures, but also the intersection point of Confucian, Buddhist, Islamic, Christian, and other civilizations. South China and its coastal islands constitute the major part of marine China (Wang 2004), that is, the South China Sea, geographically referring to the narrow and long sea area covering "Guangdong, Guangxi, Fujian and the Taiwan Strait to the north, the Philippines to the east and the Malay Peninsula to the southwest, which connects South China, Indochina Peninsula and Southeast Asia islands" (Ma 2012), as well as its surrounding sea areas.

Many scholars put forward their own research framework on how to study this area, like Philip A. Kuhn's "Corridor-niche model," Prasenjit Duara's concept of "regional Asia," as well as the "world unit" concept promoted by Japanese scholars, etc. From a customary perspective, the islands of the South China Sea 
Rim are located in "remote" and "marginal" areas, the former referring to the geographical position, and the latter the cognition position as a result of the former, signifying both the frontier of China and the edge of the world. The perspective of "viewing the world through the island" found in this paper views islands as the field where various powers meet and observes the dynamic process of "the interaction between you and me." The proposal of "the island world" concept shows the time-space conversion between center and edge, and furthermore the transformation of the island world undergoing cultural exchange and integration in such an open and mobile space against the center-edge opposition as well. In this perspective, most of the islands in the South China Sea were in the spreading circle of Chinese culture and thus were the merging field from continent to ocean and from the world to China. Some scholars have pointed out that the long-term socioeconomic exchange formulated a very distinctive economic circle in the South China Sea, consisting of port cities, especially island port cities, including Hong Kong, Kaohsiung, Tainan, Jinmen, as well as Malacca, Kuala Lumpur, Penang, Singapore, Surabaya, Semarang, Manila and other cities in Southeast Asia (Yifeng 2002). The trade network constituted by these spots showed another dimension of the island world - that is, connecting the world economic trading system. For example, in 1726, Dutch missionaries named Qijin Island of Kaohsiung in Taiwan "Handelars Eylant" or "Traders Island" on the map they compiled, where was the exact trading area of fishing boats. It later became the core area and trading center of Kaohsiung, and an international business harbor instead of its original fishing and trading port.

The establishment and development of island port cities involved the island world into the cross-regional social system, highlighting the significance of islands in the global system. The extension of such cities or urban landscapes implicated the multi-layer globalization and the transformation of politics and society. Moreover the multi-layer symbolism demonstrated the cross-cultural characteristics. With the interaction of marine trade, historic memories, architecture arts of island cities, the social and cultural integration were being inherited and were evolving in a way that demonstrated the regional cultural characteristics of the South China Sea. Island cities played important cultural, economic, political and environmental roles in local societies, and in regional and global societies as well, many of which were developing in terms of international commerce and political operations. The studies of island cities or urban areas from an internal perspective breaks the tendency of viewing the island from a peripheral, isolated and marginal perspective while making up for the defect in the island-oriented urban studies, revealing a brand new cross-disciplinary field and looking forward to fruitful results after longterm fieldwork studies.

\section{The island world in globalization context: transformation and adjustment}

The island involvement in the global system has always been going on with the times. Not only is the world open to islands (Kottak 2012), but also islands are open to the world. The major impetus for the openness can be attributed to 
population migration and tourism development. Based on studies of the marriage circle and marriage strategy of the people of Dajin Island in Taishan, Guangdong, scholars revealed the marital process from internal island to external island that greatly affected the lifestyle and the marriage strategy of Dajin residents, and that was also a manifestation of the island world's openness (Tao 2016). Moreover, the specific environment and rich resources attracted tourists from all around the world, breaking up the closed state of the island, promoting the robust multiple development of local economy on one hand and raising risks to the natural environment and ecological resources on the other (Gössling and Wall 2007). In Hainan, the leisure tourism in Wenchang and the clam handicraft industry of Tanmen are the results of local livelihood transformation, meanwhile Sanya is changing into a yacht marina and gradually embracing more openness to tourism development.

Under the dramatic transformation of current island world, islands are opening on a larger scale and in a greater depth, representing the epitome of globalization and the rapid modernization process, as well as revealing an integration process of regional or global economic development with islands' traditional production. The adaptive strategies and development approaches of islands under such circumstances are the new aspects of island studies.

In the South China Sea, the "maritime prohibition" period in Chinese history arose firstly in the process of the continentalization of islands. Before the Ming dynasty, fishermen of Weizhou engaged in pearl-diving and fishing production. Though documents on the island could be found occasionally, it has never really entered into the national vision. The Ming government implemented the "pearl-diving ban" policy, and set up institutions to crack down illegal pearl-diving. Weizhou thus became a key spot in the coastal defense system even then. During the early Qing dynasty, although the "pearl-diving ban" policy was repealed, its strategy had been stuck in a dilemma between ban and ban-lifting for quite a long time. Because of the difficulties in implementing coastal defense, "foreign pirates" took the island as a stronghold and plagued the area in the middle Qing dynasty. Until the late Qing dynasty, forced by diplomatic relations, the government first permitted foreign pilgrims' immigration to the island under French missionaries' help, and lifted the ban after that and established the county-level government, completing its transition from "a pirate-plagued area" to "an administrative area." Weizhou witnessed the social transformation process from a desolate island and a thieves' den into a national administration system, which reflected a complicated interaction between island development and the macro-scope history of the national power's expansion to the coastal society during the Ming and Qing dynasties (Xianbo 2011).

Concerning the continentalization of islands, the Dan people are an example of such a case. The Dan, who are also called "the residents on the water," are widely distributed in the South China Sea and through Southeast Asia, where they use boats as their home. Apart from living in inland-river and sea areas like Guangdong, Fujian, Guangxi and Hainan, they also migrated to Southeast Asian countries like Thailand, etc. (Qin 2006) The Dan in Hainan emerged no later than the Northern Song dynasty. Nowadays, they are mainly distributed in Sanya, Lingshui, Changjiang, etc. (Zuan 2013), and most of them have already settled on land. Their livelihood is of the "mobile fishing" pattern, falling exactly into the category of 
"the ethnic group on the sea" (Pan 2015). Those who once lived on the water are now settled on the land, the process of which reflects an important aspect of island continentalization.

The continentalization process reached its peak in Taiwan with the total number of residents moving away from an island. From 1965 to 1966, Wang Songxing did a fieldwork study on Guishan Island, where 639 residents from 89 households inhabited an area of $2.841 \mathrm{~km}^{2}$ with less than one seventh of it being the habitable area. The nearest town, Toucheng, is $9.76 \mathrm{~km}$ away from the island. A population of 700 was about its maximum capacity, and the excessive population rushed out to Yilan county (Wang 1967). In 1977, all the local residents including 723 people from 131 households decided to move to Toucheng (Meiyu 1996). On December 22, 1999, Guishan was semi-opened to the outside, and on August 1, 2000, it was officially opened to the outside and developed into a maritime ecological park as a tourist attraction under the concept of sustainable ecological development based on the premise of limiting the number of tourists.

Recently, many offshore islands joined the continent through land reclamation, while others, were joined by bridge, causeway, or tunnel. Xiaozuo Island, in Hui'an, Fujian province was once an island; in 1958 it became a peninsula through land reclamation and road construction (Min 2000). Qi'ao Island, of Zhuhai, Guangdong province was once under closed or semi-closed status with the only contact through fishing boats. The completion of Qi'ao Bridge in February, 2001, by the Zhuhai municipal government, greatly facilitated the transportation to and from the island, connecting it with the downtown city and expediting its development.

In the process of globalization and modernization, Hainan exposed some development issues during its continentalization. It belongs to the island cultural system developed under the mutual promotion of the continental and marine system (Ma 2014). For a long time, the national development vision for Hainan has always been short-term oriented projects to achieve strategic objectives. In the 1950s, the introduction of rubber-planting and the establishment of state-owned plantations led to a long-term single crop economy in the island, which didn't take into consideration the survival and the development of local ethnic groups, and caused a phenomenon of "rich island, poor ethnicities" (Xiaotong 1987). In its development planning, the economy and culture of the $\mathrm{Li}$ and Miao people have been neglected. (Xiaotong 2009. Xiaotong (1987) proposed that the development of Hainan should be centered on local people; he paid attention to the unbalanced development within the island and emphasized the development of ethnicities in the development of ethnic regions. Guanqiong (1991) also pointed out that Hainan's development should not neglect the cultural structure and the wholeness of the island world in the specific ecological environment. Moreover, from the west to the east in Hainan, its fishery production showed the trend changing from fishing to aquaculture, yet more evidence of continentalization. Along with the development of the island as an international tourist destination and the establishment of free trade zone, plus the increasing "migrant bird" groups, the continentalization in the structure of Hainan's population is more and more obvious.

In the context of globalization, from the Pacific islands to the Indian Ocean islands and even the Caribbean islands, all the islands around the world have 
undergone dramatic changes. As Sahlins (1993) stated, the world was in a largescale structural transformation process, within which social change presented its own authenticity in its unique way, and global modernity reemerged in the form of local diversity. This could be considered as a cultural consciousness process of the island world in its strategic adjustment and seeking for orderly development. In a sense, islands reflect a gradual spectrum of mixed-up differences (Geertz 1988), converging different peoples, and products from all around the world that integrate with each other in the transformation process, and with islands themselves coping with constant self-adjustment.

In the 1980s, the Indonesian government protected the ethnic culture in Bali through its revitalization policy toward folk arts, techniques, and traditional customs, which directly infiltrated into local people's daily lives. New things were created based on traditional arts. To some extent, Balinese ethnic culture's implantation into the "local culture" which was also the "national culture" of Indonesia created and reproduced a kind of regional culture. Bali held glamorous religious rituals which were supported by the government and were also the foundation of cultural identity (Ma 2000). This is a successful case of island adaption and adjustment.

As a famous tourist destination, Fiji is the center of transportation, education, medical care, politics and economy in the South Pacific. As a multi-ethnic nation, its aboriginal and Indian populations are the largest, and the country is also home to the descendants of the British, who were once the rulers, as well as peoples of Chinese and Korean origin (Kawai 2009). After recent social transformation, the traditional tribal chieftain system remained, while a completely modern administrative system has been established in the region centering on the capital city Suva. Fijians understood and accepted this changing world by their intrinsic worldview. Modern Fijian society has indeed become involved in the complicated modern system and the currency economy, but Fijians have never abandoned their traditional culture, or in other words, their traditional culture has never disappeared, which means that political economic globalization has not fully restricted the local social life system. They tried to form their own world through changing the interaction between local people and the local conception of nature, through the connection with the symbiotic system of external factors. They integrated foreign culture with Fijian traditions to cope with the impacts of globalization. Taking the importation of Christianity and Western sports for instance, Fijians distinguished them from their traditional culture on one hand, and recognized them as their traditional sports on the other. This is another successful case of island adaption and adjustment.

\section{Conclusion and discussion}

In current socio-cultural studies related to islands, the perspective and dimension of "viewing the world through islands" is still dominant. The concept of "island world" proposed by this paper emphasizes the connecting system found between islands. Island society has its particularities and generalities as well. Traditional anthropologists considered islands isolated and therefore searched for their so-called "otherness." In fact, islands are not isolated in the ways those anthropologists thought, but they are in fact connected by marine transportation and are under 
constant external influence. The anthropological island studies in this paper are based on the general island studies in the field of anthropology. Furthermore, can't the generality pursued by traditional anthropologists be considered as "continentality" particularly? Everyone who has been living or doing fieldwork on an island can easily experience the differences. The proposal of island society and continental society is exactly the perspective of viewing the world through the lens of the island, resulting in this pair of corresponding concepts. In the backdrop of globalization, island social culture is changing dramatically. We must jump out of the existing framework, travel from the continental world to the island world, view the world through islands and explore a new methodology of island studies.

The South China Sea Rim, and China and Southeast Asia in particular, is a regional community with a shared future and common interests. Therefore, the study of this region is both of academic value and of realistic meaning. Firstly, the significance of the concept centering on "the island world" lies in the interpretation of how to construct islands as a maritime station to connect the interactions and network between land and sea and between the world and, in this case, China, and the enhancement of the knowledge and understanding of islands under globalization which bring changes in island-research methodology. Secondly, the importance and influence of human-land relationships should be considered in the study of the island world. In the regional context and long-term examination, we need to analyze the integrity and particularity of islands, the connection between islands, and especially present the historical context of island diversity under the complex network in terms of population migration, urban development, social integration, and cultural exchange. Moreover, the perspective of island transformation and adaption under the background of globalization can deepen the understanding of the South China Sea Rim and its islands from multiple aspects, and enrich the knowledge of human civilization types and its evolution process by depicting the integration and development of different civilizations on these islands within the Rim while providing valuable realistic achievements for current political and economic patterns of the South China Sea Rim.

Xiaotong (1980) once pointed out clearly in the article titled "Anthropology towards the people", "Sometimes, after reading my teacher's works, these problems suddenly arise: How are these lovely Trobriand islanders right now? Have they read these analyses of their social life? What will they think about their life after they read them? What will they do to their own society?" In fact, today's anthropological island studies should pay more attention to the survival and development of islanders, which is also the core issue that inter-disciplinary island studies will face in the future.

Acknowledgements Not applicable.

\section{Author's contributions}

The author read and approved the final manuscript. 


\section{Funding}

This paper belongs to a phased result of the research project titled "'Elite class' and current studies on the stability of domestic frontier ethnic areas" funded by The National Social Science Fund of China (Project number: 16BMZ011).

\section{Availability of data and materials}

Not applicable.

\section{Ethics approval and consent to participate}

Not applicable.

\section{Consent for publication}

Not applicable.

\section{Competing interests}

Not applicable.

\section{References}

Abu-Lughod, Janet L. 1989. Before European hegemony: the world system A.D.1250-1350, 35. New York Oxford: Oxford University Press.

Baldacchino, Godfrey. 2006. Islands, island studies, island studies journal. Island Studies Journal 1: 1.

Baldacchino, Godfrey. 2008. Studying islands: on whose terms? Some epistemological and methodological challenges to the pursuit of island studies. Island Studies Journal 3: 1.

Geertz, C. 1988. Works and lives, the anthropology as author. Vol. 148. Cambridge: Polity Press.

Geertz, Clifford. 1983. Local Knowledge: Further Essays in Interpretive Anthropology, 56-57. New York: Basic Books.

Gössling, Stefan, and Geoffrey Wall. 2007. Island tourism. In A World of Islands: An Island Studies Reader, Institute of Island Studies, University of Prince Edward Island, Canada, in collaboration with Agenda Academic, Malta, ed. Godfrey Baldacchino, 429-448.

Guanqiong, Rong. "The fundamental way out for the reform in Li ethnicity region is to change people--on Hainan economic development strategy," edited by Guangdong Ethnology Society, Guangdong Ethnology Institute, Essays on Guangdong Ethnology Studies《广东民族研究论从》, Vol.5, Guangdong People's Publishing House(广东人民出版社), 1991.

Jing, Peng, and Hong Zhu. 2007. The island effect and the point-axis model in the Catholic transmission and expansion process in Beibu Bay of Guangxi province. Human Geography(《人文地理》) 4: 113-118.

Kawai, Toshimits. translated by Jiang Na, Proofreading by Ma Guoqing, "Body and life system-the sociocultural inheritance of Fiji islands in southern Pacific," Open Times(《开放时代》), Vol.7, 2009.

Kexin, Chen, and Chen Jiagang. 2002. The sustainable use of island resources in China. Journal of Tianjin Normal University(《天津师范大学学报》) 1: 60-63.

Kottak, Conrad. 2012. translated by Zhang Jingwei, Xing Yingying and Ma Dandan, Assault on Paradise-the Globalization of a Little Community in Brazil, 32-35. Beijing: Peking University Press. 
Li, Liu. 2014. Fishing rights and the sea power-a historical study of fishermen on Hainan island and its practical meanings. Journal of Sun Yatsen University《中山大学学报》3: 136-144.

Lihai, Zhao. 1995. Some legal issues on the South China Sea islands. Law and Social Development(《法制与 社会发展》) 4: 50-63.

Ma, Guoqing. 2000. Globalization: cultural production and identity--ethnicity, local society and transnational cultural circle. Journal of Peking University(《北京大学学报》) 4: 152-161.

Ma, Guoqing. 2012. Culture, ethnicity and society: an introduction of the South China Sea Rim study. Ethno-national studies, (《民族研究》) 2: 34-43.

Ma, Guoqing. 2014. Hainan island: laboratory of Chinese anthropological studies. Journal of Guangxi University for Nationalities(《广西民族大学学报》) 5: 36-44.

Malinowski, Bronislaw. 2009. translated by Zhang Yunjiang, Argonauts of the western Pacific. Beijing: China Social Sciences Press(中国社会科学出版社).

Manners, R.A. 1965. Remittances and the unit of analysis in anthropological Research. Southwestern Journal of Anthropology 21 (3).

McCall, Grant. "Nissology: the study of islands", Journal of the Pacific Society,Vol.17,No.2-3,1994; Grant McCall, "Clear confusion in a disembedded world: the case of Nissology," Geographische Zeitschrift, Vol.84, No.2, 1996.

McNeill, J. R. translated by He Meilan, "Of Rats and Men: a synoptic environmental history of the Island Pacific," edited by Xia Jiguo and Jerry Bentley, Journal of World History(《全球史读本》), Beijing: Peking University Press, 2010, 205-247.

Meiyu, Lü. "A study on population migration and environment adaption of Guishan island", doctoral dissertation of Chinese Culture University of Taiwan, China, 1996, 191.

Min, Xia. 2000. The Mystery of the Red Headband Village, Shanghai Literature \& art Publishing House(上 海文艺出版社).

Pan, Yinghai. 2015. The Dan's material civilization and marine culture: a perspective on cultural ecology. The Tianya Journal of Humanities 4: 86-95.

Qin Pu. "Transformation and identification-a case study of residents on the water in Ayutthaya, Thailand," master's degree thesis, Guangxi University for Nationalities, 2006.

Royle, Stephen A. 2007. "Island definitions and typologies," A world of Islands: An island Studies Reader, Godfrey Baldacchino ed. Institute of Island Studies, University of Prince Edward, 34. Malta: Canada, in collaboration with Agenda Academic.

Sahlins, Marshall. 1993. Goodbye to Tristes Tropes: ethnography in the context of modern world history. Journal of Modern History 65 (1).

Sahlins, Marshall. 2003. translated by Lan Daju, Islands of History, Shanghai People's Publishing House(上. 海人民出版社). Shanghai.

Sheng, Geng. "From the death of Francois Xavier in Shangchuan to the Jesuits' flooding into China," edited by Chinese Society for Historians of China's Foreign Relations, Institute of Japanese Culture of Zhejiang University, and the Institute of Overseas Chinese Studies of Jinan University, A Collections of Sino-foreign Relations History Vol. 14: Sino-foreign Relations History from a New Perspective, Lanzhou: Gansu people's Publishing House(甘肃人民出版社), 2008.

Tao, Fan. 2016. Social marriage circle and marriage strategy- a case study of Dajin Island of Taishan, Guangdong. In Social Transformation and Family Strategy, ed. Ma Guoqing, 109-120. World publishing corporation (世界图书出版公司).

Wallerstein, Immanuel Maurice. 2013. translated by Guo Fang, The Modern World System. Beijing: Social Science Academic Press(社会科学文献出版社.

Wang, Gengwu. translated by Zhao Dianhong, Ocean China in the transformation period, Jinan History (《暨南史学》)Vol. 3, Guangzhou: Jinan University Press(暨南大学出版社), 2004, 403-411.

Wang, Libing. 2015. Flow, network and boundary: the marine adaption studies on Tanmen fishermen, doctoral dissertation of Xiamen University.

Wang, Songxing. 1967. Guishan island: A study of Han fishing society. China: Institute of Ethnology, Academia Sinica of Taibei.

Wu, Xiaomei, and Zhou Jinyan. 2015. The flowing "center": the space study of Mazu belief in Meizhou island. Folklore Studies(《民俗研究》) 1: 149-158.

Xianbo, Chen. 2011. From a thieves' den of a desolate island to a community town-the development of islands in the South China Sea during the Ming and Qing dynasties based on the case study of Weizhou Island. Review of Chinese Social History(《中国社会历史评论》) 12: 275-297.

Xiaotong, Fei. 1980. Anthropology toward the people. Social Science Frontier(《社会科学战线》) 3: 109-114. 
Xiaotong, Fei. 1987. On the development of Hainan island's ethnic area, Vol.1, Outlook Weekly(《瞭望周 刊》), Vol.12.

Xiaotong, Fei. 2009. Developing ethnic economy under the full play of ethnic advantages, Fei Xiaotong Anthology, Vol.12(《费孝通文集第十二卷), 306-307. Inner Mongolia People's Publishing House(内蒙古 人民出版社).

Xincheng, Liu. 2009. Constituting the world history in interactions, Guang Ming Daily (《光明日报》).

Yifeng, Dai. 2002. A research outline on transnational network of modern-time Chinese merchants in South China Sea Rim. The Journal of Chinese Social and Economic History(《中国社会经济史研究》) 1: 70-81.

Zhaorui, Liu. 2006. An essay on the cemetery of Francois Xavier in Shangchuan island. In search of $\operatorname{Root}(《$ 寻根》), vol. 6, 47-53.

Zhongqing, Xiong. 2015. Asian spices trade and the social transformation of Maluku islands of Indonesia. Journal of Sun Yatsen University 3: 151-160.

Zuan, Ou. 2013. The historical transformation of ethnicities on the sea. The Tianya Journal of Humanities(《天涯华文》) 1: 63-65.

\section{Publisher's Note}

Springer Nature remains neutral with regard to jurisdictional claims in published maps and institutional affiliations. 